\title{
Radiological Findings in Patients with COVID-19
}

\author{
Sahar Fatima ${ }^{1}$, Iqbal Ratnani ${ }^{2}$, Maha Husain ${ }^{3}$, Salim Surani ${ }^{4,5,6}$ \\ 1. Critical Care, Houston Methodist Hospital, Houston, USA 2. Critical Care Medicine, Debakey Heart and Vascular \\ Center, Houston, USA 3. Internal Medicine, Dow International Medical College, Karachi, PAK 4. Internal Medicine, \\ Texas A\&M Health Science Center, Bryan, USA 5. Internal Medicine, Corpus Christi Medical Center, Corpus Christi, \\ USA 6. Internal Medicine, University of North Texas, Dallas, USA
}

Corresponding author: Sahar Fatima, saharfatima164@gmail.com

\begin{abstract}
After its origin in Wuhan, China, coronavirus related respiratory illness spread across the globe, being declared as a pandemic by WHO on March 13, 2020. Because it is acquired via respiratory droplets, community spread is responsible for the recent global crisis. The current diagnostic options include realtime polymerase chain reaction (RT-PCR) and a few serology tests, including but not limited to the recently approved five minutes serology tests. The disease presents as a lower respiratory tract illness. Anecdotal experiences have shown that imaging characteristics are crucial to diagnosis as radiological evidence of disease appears prior to clinical manifestations and tends to evolve over time, which can be useful in predicting the stage of the disease. CT scan is more sensitive than a chest X-ray in highlighting these changes.
\end{abstract}

Categories: Infectious Disease, Epidemiology/Public Health

Keywords: coronavirus pandemic, covid-19, radiological findings

\section{Introduction And Background}

Affecting 1,099,389 people and claiming 58,901 human lives [1], the coronavirus related pandemic is one of the deadliest known epidemics in recent times. These numbers are increasing exponentially and, with no definitive treatment or available vaccine in sight, creating havoc for the health and financial systems of the world.

The earliest reported cases were in Wuhan, the capital city of Hubei province in China. These cases were treated as pneumonia of an unknown origin. As the disease spread, China alarmed the World Health Organization (WHO) of the presence in Wuhan of several cases of an unusual type of pneumonia. Researchers discovered that the pathogen responsible for the respiratory illness was a novel strain of the family Coronaviradae, which is similar to two previous epidemics, namely Middle Eastern Respiratory Syndrome (MERS) and Severe Acute Respiratory Syndrome (SARS). This new illness was named SARS-CoV-2 by the International Committee on Taxonomy of Viruses (ICTV) on February 11, 2020. The WHO officially

Received 04/06/2020 Review began 04/09/2020 Review ended 04/09/2020 Published 04/12/2020

\section{(c) Copyright 2020}

Fatima et al. This is an open access article distributed under the terms of the Creative Commons Attribution License CC-BY 4.0., which permits unrestricted use, distribution, and reproduction in any medium, provided the original author and source are credited. labeled the disease caused by SARS-CoV-2 as COVID-19 in the International Classification of Diseases (ICD) [2].

\section{Review}

Coronavirus infection, although initiated by bat-to-human spread, is now mainly acquired through humanto-human spread (i.e., community spread) via contact, respiratory droplets, and also airborne being contemplated [3]. The infection mainly targets the respiratory system. The spike protein, also known as the S protein, binds to the angiotensin-converting enzyme 2 (ACE2) receptor expressed in the alveolar epithelium; this pathophysiology explains the predominance of respiratory symptoms [4].

\section{Diagnosis}

The immediate diagnosis is extremely critical for initiating treatment and containing the disease spread. Currently available diagnostic modalities include laboratory testing with RT-PCR and imaging with chest Xray and CT scan. Laboratory testing mainly relies on PCR done on samples obtained from the upper and lower respiratory tract and was approved by the Center for Disease Control (CDC) on March 3, 2020 [5]. RTPCR is highly specific (i.e., 95-97\%) but has a low sensitivity of 60-70\% [6, 7]. There are a number of serology tests available, and on March 27, 2020, the Food and Drug Administration (FDA) approved a five minutes serology test kit [8].

The radiological perspective used for disease assessment and follow-up is very helpful. It provides a direct insight into the pathophysiology of the disease process. As the coronavirus related respiratory illness presents clinically as pneumonia, predominant imaging findings are that of an atypical or organizing pneumonia [7, 9]. Although chest X-rays are less sensitive than CT scans, the former may be used as a firstline approach because of their availability and ease of decontamination. Chest X-ray findings may be normal earlier in the clinical course and tend to peak 10-12 days after the onset of clinical symptoms [10]. Figure 1 


\section{Cureus}

represents early and late-stage X-ray findings in patients with COVID-19.

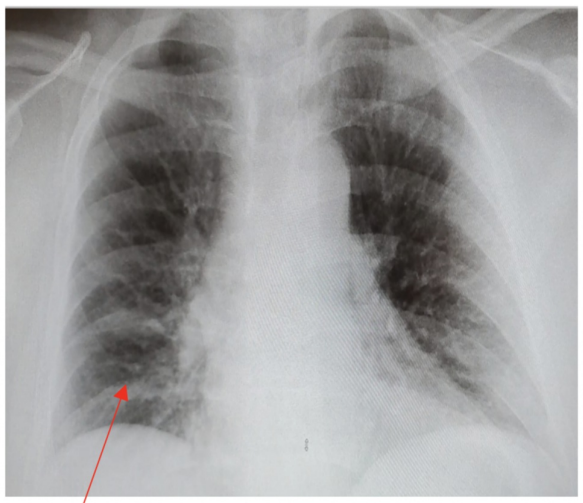

Early stage chest $\mathrm{X}$ ray may be norma or manifest very subtle changes such as ill-defined consolidation in lower lobes

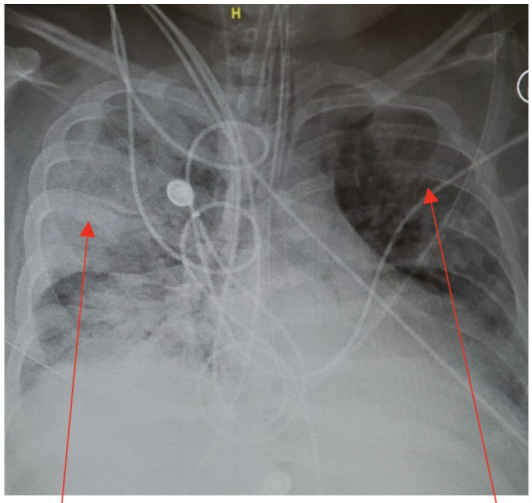

Late stage chest $X$ ray shows an ARDS like pan-lobar pattern of lung involvement, multiple consolidations, disruption of lung architecture requiring endotracheal support.

\section{FIGURE 1: Early and late-stage X-ray findings in patients with COVID-19}

ARDS - acute respiratory distress syndrome

Chest CT has greater sensitivity as compared to RT-PCR in diagnosing COVID-19 [11]. There has been a lot of debate on using a CT scan as the front-line screening tool for diagnosing COVID-19 [10]. In fact, CT findings begin to appear even before a positive COVID-19 lab result [12]. According to Jin et al., the characteristic CT scan findings evolve in five different phases, as shown in Figure 2 [13].

\begin{tabular}{|c|c|c|c|c|c|}
\hline & Ultra-Early Stage & Early Stage & $\begin{array}{c}\text { Rapid progression } \\
\text { Stage }\end{array}$ & $\begin{array}{c}\text { Consolidation } \\
\text { Stage }\end{array}$ & Dissipation Stage \\
\hline \multirow[t]{3}{*}{ Findings } & $\begin{array}{l}\text {-Prior to symptom } \\
\text { onset. } \\
\text {-Throat swab positive, } \\
\text { laboratory negative } \\
\text { - Usually within 1-2 } \\
\text { weeks of exposure. }\end{array}$ & $\begin{array}{l}\text { Patients present with } \\
\text { symptoms (within 1-3 } \\
\text { days of symptoms like } \\
\text { fever, dry cough). } \\
\text { On histopathology - } \\
\text { There is congestion of } \\
\text { alveolar capillaries } \\
\text { resulting in alveolar } \\
\text { and interlobular } \\
\text { interstitial edema. }\end{array}$ & $\begin{array}{l}\text { This stage follows } \\
\text { within } 3-7 \text { days of } \\
\text { symptomatic } \\
\text { presentation. } \\
\text { - There is an } \\
\text { escalation in the } \\
\text { hyperinflammatory } \\
\text { response. Fibrous } \\
\text { extensions that } \\
\text { connect the alveoli } \\
\text { begin to develop. }\end{array}$ & $\begin{array}{l}\text { - This phase coincides } \\
\text { with } 2^{\text {nd }} \text { week of } \\
\text { clinical symptoms. } \\
\text { - The vascular } \\
\text { congestion } \\
\text { diminishes and } \\
\text { fibrosis } \\
\text { predominates. }\end{array}$ & $\begin{array}{l}\text { - It occurs about 2-3 } \\
\text { weeks after initial } \\
\text { symptomatic } \\
\text { presentation. } \\
\text { - There is more of a } \\
\text { healing and repair } \\
\text { response within the } \\
\text { lungs. }\end{array}$ \\
\hline & & & & & \\
\hline & $\begin{array}{l}\text { CT scan demonstrates } \\
\text { Bilateral, subpleural, } \\
\text { multiple scattered } \\
\text { ground glass opacities. }\end{array}$ & $\begin{array}{l}\text { CT scan shows multiple, } \\
\text { bilateral ground glass } \\
\text { opacities. Irregular, } \\
\text { interlobular septa begin } \\
\text { to develop. }\end{array}$ & $\begin{array}{l}\text { CT findings include } \\
\text { subpleural, posterior } \\
\text { consolidations, } \\
\text { dispersed air } \\
\text { bronchograms along } \\
\text { with superimposed } \\
\text { irregular septa. }\end{array}$ & $\begin{array}{l}\text { There is a decrease in } \\
\text { size and density of } \\
\text { consolidations. }\end{array}$ & $\begin{array}{l}\text { CT scan shows patchy } \\
\text { consolidation, reticular } \\
\text { opacities (strip-like } \\
\text { opacities), bronchial } \\
\text { and interlobular septal } \\
\text { thickening. }\end{array}$ \\
\hline
\end{tabular}

FIGURE 2: CT scan stages in patients with COVID-19

\section{Lung ultrasound}

According to Soldati et al., lung ultrasound (LUS) can detect changes in superficial lung parenchyma with greater accuracy as compared to chest X-rays and can, therefore, play an important role in triage, diagnosis and prognostic stratification of patients in the emergency room (ER) and intensive care unit (ICU) setting [14]. Poggiali and her colleagues recently published a report that suggests that ultrasound findings in patients with COVID-19 pneumonia correlated with CT findings, which signifies that LUS could be useful for early diagnosis of COVID-19 pneumonia in patients presenting to the ER [15]. 


\section{Cureus}
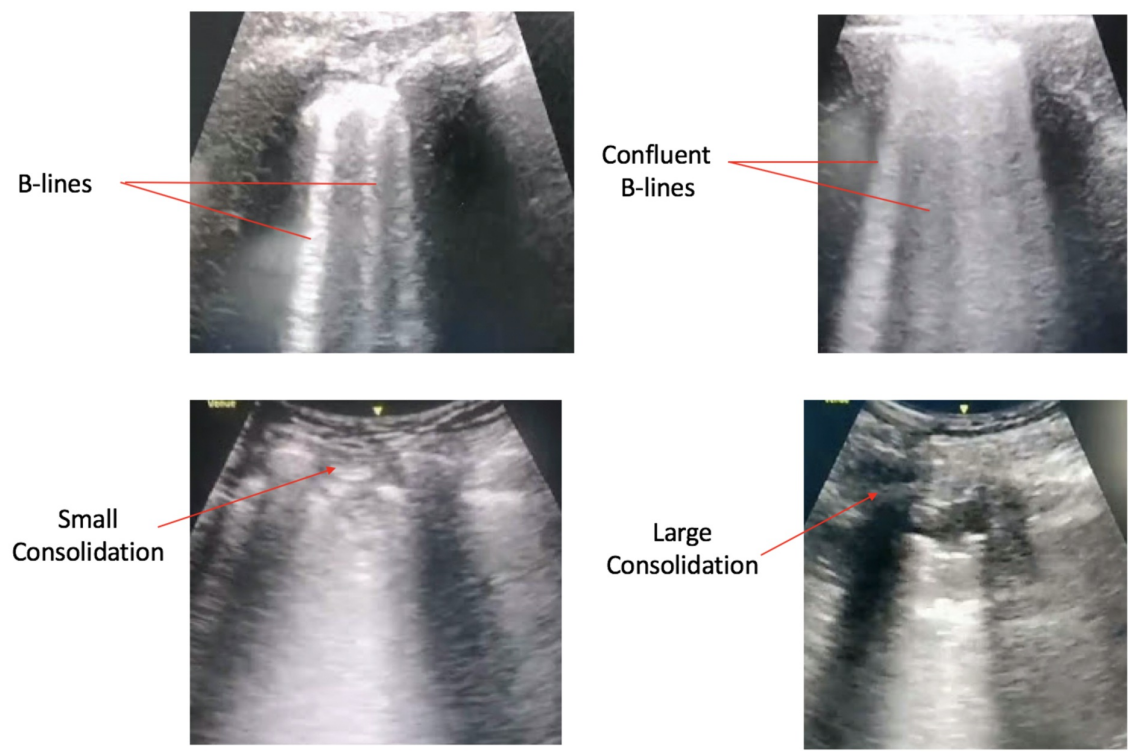

FIGURE 3: Lung ultrasound findings in patients with COVID-19

\section{Conclusions}

Although most of the patients completely recovered from the disease, they are likely to have some kind of long- term lung damage. Only time will reveal the magnitude of irreversible parenchymal lung injury. Radiological findings are very helpful in predicting the clinical course of the disease and may be used to monitor long-term consequences. There is a lot of research currently being done. With the abundance of new information available, we are observing changing trends in diagnostic and therapeutic approaches to the disease.

\section{Additional Information}

\section{Disclosures}

Conflicts of interest: In compliance with the ICMJE uniform disclosure form, all authors declare the following: Payment/services info: All authors have declared that no financial support was received from any organization for the submitted work. Financial relationships: All authors have declared that they have no financial relationships at present or within the previous three years with any organizations that might have an interest in the submitted work. Other relationships: All authors have declared that there are no other relationships or activities that could appear to have influenced the submitted work.

\section{References}

1. COVID-19 Dashboard by the Center for Systems Science and Engineering (CSSE) at Johns Hopkins University (JHU). (2020). Accessed: 4/1/2020: https://coronavirus.jhu.edu/map.html.

2. Naming the coronavirus disease (COVID-19) and the virus that causes it; World Health Organization (WHO). (2020). Accessed: 4/2/2020: https://www.who.int/emergencies/diseases/novel-coronavirus2019/technical-guidance/naming-the-coronavirus-disease-(co....

3. Coronavirus disease 2019, Situation Summary; Centers for Disease Control and Prevention (CDC) . (3/18/2020). Accessed: 4/2/2020: https://www.cdc.gov/coronavirus/2019-ncov/cases-updates/summary.html.

4. Zhou P, Yang X, Wang X, et al.: A pneumonia outbreak associated with a new coronavirus of probable bat origin. Nature. 2020, 579:270-273. 10.1038/s41586-020-2012-7

5. CDC Tests for COVID-19; Center for Disease Control and Prevention . (2020). Accessed: 4/1/2020: https://www.cdc.gov/coronavirus/2019-ncov/about/testing.html

6. Mossa-Basha M, Meltzer CC, Kim DC, Tuite MJ, Kolli KP, Tan BS: Preparedness for COVID-19: Radiology Scientific Expert Panel. Radiology. 2020, Accessed: 4/1/2020: 10.1148/radiol.2020200988

7. Kanne JP, Little BP, Chung JH, Elicker BM, Ketai LH: Essentials for radiologists on COVID- 19: an update Radiology Scientific Expert Panel. Radiology. 2020, Accessed: 4/1/2020: 10.1148/radiol.2020200527

8. Detect COVID-19 in as little as 5 minutes; Abbott . (2020). Accessed: 4/1/2020: https://www.abbott.com/corpnewsroom/product-and-innovation/detect-covid-19-in-as-little-as-5minutes.html.

9. Kooraki S, Hosseiny M, Myers L, Gholamrezanezhad A: Coronavirus (COVID-19) outbreak: what the department of radiology should know. J Am Coll Radiol. 2020, 17:447-451. 10.1016/i.jacr.2020.02.008

10. Wong HYF, Lam HYS, Fong AH, et. al: Frequency and distribution of chest radiographic findings in COVID19 positive patients. Radiology. 2020, Accessed: 4/1/2020: 10.1148/radiol.2020201160

11. Ai T, Yang Z, Hou H, et. al: Correlation of chest CT and RT-PCR testing in coronavirus disease 2019 


\section{Cureus}

(COVID-19) in China: a report of 1014 cases. Radiology. 2020, Accessed: 4/1/2020:

10.1148/radiol.2020200642

12. Kenny JES, Canepa CM: An illustrated guide to the chest CT in COVID . PulmCCM. 2020, Accessed: 4/1/2020: https://pulmccm.org/uncategorized/an-illustrated-guide-to-the-chest-ct-in-covid-19/ .

13. Jin Y, Cai L, Cheng Z, et al.: A rapid advice guideline for the diagnosis and treatment of 2019 novel coronavirus (2019-nCoV) infected pneumonia (standard version). Mil Med Res. 2020, 7:16. 10.1186/s40779. 020-0233-6

14. Soldati G, Smargiassi A, R Inchingolo, et. al.: Is there a role for lung ultrasound during the COVID-19 pandemic?. J Ultrasound Med. 2020, in press: 10.1002/jum.15284

15. Poggiali E, Dacrema A, Bastoni D, et. al.: Can lung US help critical care clinicians in the early diagnosis of novel coronavirus (COVID-19) pneumonia?. Radiology. 2020, Accessed: 4/1/2020:

10.1148/radiol.2020200847 